\title{
Pontibacillus marinus sp. nov., a moderately halophilic bacterium from a solar saltern, and emended description of the genus Pontibacillus
}

\author{
Correspondence \\ Chang-Jin Kim \\ changjin@kribb.re.kr
}

\author{
Jee-Min Lim, ${ }^{1}$ Che Ok Jeon, ${ }^{2}$ Dong-Jin Park, ${ }^{1}$ Hye-Ryoung Kim, ${ }^{1}$ \\ Byoung-Jun Yoon ${ }^{1}$ and Chang-Jin Kim ${ }^{1}$
${ }^{1}$ Korea Research Institute of Bioscience and Biotechnology, 52 Oeundong, Yusong, Daejeon 305-333, Republic of Korea Jinju 660-701, Korea \\ ${ }^{2}$ Environmental Biotechnology National Core Research Center, Gyeongsang National University,
}

\begin{abstract}
A moderately halophilic, Gram-positive, rod-shaped bacterium $\left(\mathrm{BH} 030004^{\top}\right)$ was isolated from a solar saltern in Korea. Phylogenetic analysis based on 16S rRNA gene sequences showed that strain $\mathrm{BH} 030004^{\top}$ belonged to the genus Pontibacillus. Chemotaxonomic data (DNA G+C content, $42 \mathrm{~mol} \%$; major isoprenoid quinone, MK-7; cell-wall type, A1 $\gamma$-type meso-diaminopimelic acid; major fatty acids, iso- $\mathrm{C}_{15: 0}$ and anteiso- $\mathrm{C}_{15: 0}$ ) also supported the affiliation of the isolate to the genus Pontibacillus. Although the 16S rRNA gene sequence similarity between strain $\mathrm{BH} 030004^{\top}$ and Pontibacillus chungwhensis DSM $16287^{\top}$ was relatively high $(99 \cdot 1 \%)$, physiological properties and DNA-DNA hybridization (about $7 \%$ DNA-DNA relatedness) allowed genotypic and phenotypic differentiation of strain $\mathrm{BH} 030004^{\top}$ from the type strain of $P$. chungwhensis. Therefore, strain $\mathrm{BH} 030004^{\top}$ represents a novel species of the genus Pontibacillus, for which the name Pontibacillus marinus sp. nov. is proposed. The type strain is $\mathrm{BH}_{030004^{\top}}\left(=\right.$ KCTC $3917^{\top}=$ DSM $\left.16465^{\top}\right)$.
\end{abstract}

Aerobic, spore-forming, moderately halophilic, Grampositive rods constitute a taxonomically diverse group and have been isolated from marine environments and related habitats. They were originally assigned to the genus Bacillus, but molecular and chemical analyses have shown that they form several phylogenetically distinct lineages within the group classically defined as the genus Bacillus (Ash et al., 1991; Stackebrandt \& Liesack, 1993; Nielsen et al., 1994). Some of these distinct lineages have been described as the novel genera Halobacillus (Spring et al., 1996; Yoon et al., 2003), Gracilibacillus (Wainø et al., 1999), Virgibacillus (Heyndrickx et al., 1998; Heyrman et al., 2003), Filobacillus (Schlesner et al., 2001) and Lentibacillus (Yoon et al., 2002). Recently, Lim et al. (2005) reported the species Pontibacillus chungwhensis, which is the only species described in the genus Pontibacillus to date. In this study, another novel Gram-positive bacterium belonging to the genus Pontibacillus was isolated from a solar saltern in Korea and its taxonomic status and phenotypic properties are described.

Published online ahead of print on 25 November 2004 as DOI 10.1099/ijs.0.63489-0.

The GenBank/EMBL/DDBJ accession number for the 16S rRNA gene sequence of strain $\mathrm{BH} 030004^{\top}$ is $\mathrm{AY} 603977$.

Fatty acid profiles of strain $\mathrm{BH} 30004^{\top}$ and $P$. chungwhensis DSM $16287^{\top}$ are available as supplementary material in IJSEM Online.
Strain $\mathrm{BH} 030004^{\mathrm{T}}$ was isolated from a solar saltern of the Yellow Sea in Korea, using marine agar 2216 (MA) (Difco) supplemented with $5 \%(\mathrm{w} / \mathrm{v}) \mathrm{NaCl}$ and 3 days incubation at $35^{\circ} \mathrm{C}$. Requirements for, and tolerance of, $\mathrm{NaCl}$ were determined in nutrient broth (Difco) supplemented with modified artificial sea water [containing $\left(1^{-1}\right) 0-30 \%(w / v)$ $\mathrm{NaCl}, 5.94 \mathrm{~g} \mathrm{MgSO}_{4} .7 \mathrm{H}_{2} \mathrm{O}, 4.53 \mathrm{~g} \mathrm{MgCl}_{2} .6 \mathrm{H}_{2} \mathrm{O}, 0.64 \mathrm{~g}$ $\mathrm{KCl}$ and $1.3 \mathrm{~g} \mathrm{CaCl}_{2}$. The isolates were routinely grown aerobically on MA for 2 days at $30^{\circ} \mathrm{C}$ unless otherwise indicated. Anaerobic growth was determined by incubation in an anaerobic chamber for 5 days at $30^{\circ} \mathrm{C}$ on MA. Growth was tested at different temperatures $\left(4-55^{\circ} \mathrm{C}\right)$ on MA and at different $\mathrm{pH}$ values $(5 \cdot 0-10 \cdot 0)$ in nutrient broth supplemented with artificial sea water containing $2 \cdot 36 \%(\mathrm{w} / \mathrm{v})$ $\mathrm{NaCl}$. The cellular morphology of strain $\mathrm{BH} 030004^{\mathrm{T}}$ was examined using light microscopy and transmission electron microscopy. Motility was observed at 12 and $36 \mathrm{~h}$ in wet mounts by means of a light microscope (E600 apparatus; Nikon). For visualization of flagella, cells were mounted on Formvar-coated copper grids (Electron Microscopy Science), negatively stained with $2 \%(\mathrm{w} / \mathrm{v})$ uranyl acetate for $15 \mathrm{~s}$ and then subjected to transmission electron microscopy (JEM-1010 apparatus; JEOL). Gram staining was determined using the bioMérieux Gram stain kit, according to the manufacturer's instructions. Oxidase activity was tested using a Bactident Oxidase strip (Merck) and 
catalase activity was determined by bubble production in $3 \%(\mathrm{v} / \mathrm{v})$ hydrogen peroxide solution. Nitrate reduction and hydrolysis of aesculin, casein, starch, Tween 80, urea, hypoxanthine, tyrosine, gelatin and xanthine were determined on MA as described by Lanyi (1987). Acid production from carbohydrates was tested as described by Leifson (1963); all suspension media were supplemented with artificial sea water containing $2 \cdot 36 \%(\mathrm{w} / \mathrm{v}) \mathrm{NaCl}$.

The whole-cell fatty acid profile of strain $\mathrm{BH} 030004^{\mathrm{T}}$ was determined by using GC/MS according to the instructions of the Microbial Identification System (MIDI; Microbial ID) after cultivation of the micro-organism for 2 days at $30{ }^{\circ} \mathrm{C}$ on either MA or MA supplemented with $3 \%(\mathrm{w} / \mathrm{v})$ $\mathrm{NaCl}$. The peptidoglycan and isoprenoid quinones of the strain were analysed as described by Komagata \& Suzuki (1987). The DNA G + C content of strain $\mathrm{BH} 030004^{\mathrm{T}}$ was determined by reverse-phase HPLC using the method of Tamaoka \& Komagata (1984). DNA-DNA hybridization was carried out to evaluate the genomic DNA relatedness between strain $\mathrm{BH} 030004^{\mathrm{T}}$ and P. chungwhensis KCTC $3890^{\mathrm{T}}$. Genomic DNA from the isolate and from $P$. chungwhensis $\mathrm{KCTC} 3890^{\mathrm{T}}$ was isolated and purified according to the method described by Yoon et al. (1996). The isolated DNA samples were serially diluted from 200 to $0.5 \mathrm{ng}$ and then denatured by boiling for $10 \mathrm{~min}$. The series of dilutions was applied to positively charged nylon membranes with a slot device (Schleicher \& Schuell) under a slight vacuum. Random-primed DNA labelling with digoxigenin-dUTP and hybridization were performed using a DIG High Prime DNA labelling kit and hybridization solutions (Roche Applied Science) according to the manufacturer's instructions. Detection of hybrids on the nylon membrane was performed using an enzyme immunoassay detection kit (Roche Applied Science). The membranes were incubated in $5 \mathrm{ml}$ freshly prepared Coloursubstrate solution (Roche Applied Science) for $16 \mathrm{~h}$ in the dark. The membranes were washed with distilled water and then the colour intensities of the series of dilutions were quantified using Bio-Rad GelDoc scanning software. The signals produced by self-hybridization were inferred as $100 \%$, and relatedness values (percentages) were calculated from duplicate samples.

The 16S rRNA gene sequence of strain $\mathrm{BH} 030004^{\mathrm{T}}$ was analysed as described previously (DeLong, 1992). The 16S rRNA gene sequence was aligned together with those of representative members of selected genera by using the CLUSTAL W program (Thompson et al., 1994). Sequence similarity values were computed using Similarity Matrix version 1.1 (Ribosomal Database Project II; http://rdp. cme.msu.edu/index.jsp; Cole et al., 2003). Gaps at the 5' and $3^{\prime}$ ends of the alignment were omitted for further analyses. Phylogenetic trees were constructed using three different methods, the neighbour-joining, maximumlikelihood and maximum-parsimony algorithms, available in PHYLIP software, version 3.6 (Felsenstein, 2002). Evolutionary distance matrices were calculated according to the algorithm of the Kimura two-parameter model for the neighbour-joining method. A bootstrap analysis (1000 replications) was performed, using the neighbour-joining method in the PHYLIP package, to evaluate the stability of the phylogenetic tree.

On MA, strain BH030004 ${ }^{\mathrm{T}}$ formed creamy, smooth and circular/slightly irregular colonies. It grew optimally on media containing $2-5 \%(\mathrm{w} / \mathrm{v}) \mathrm{NaCl}$, but did not grow without $\mathrm{NaCl}$ or in the presence of more than $10 \%(\mathrm{w} / \mathrm{v})$ $\mathrm{NaCl}$. The organism grew in nutrient agar (Difco) supplemented with artificial sea water, but not in nutrient agar with just $\mathrm{NaCl}$, i.e. the strain requires other salts in addition to $\mathrm{NaCl}$ for growth. Anaerobic growth was not observed in an anaerobic chamber. Growth occurred from $\mathrm{pH} 6 \cdot 0$ to $9 \cdot 0$ (optimum, $\mathrm{pH} 7 \cdot 0-7 \cdot 5$ ) and at temperatures between 15 and $40{ }^{\circ} \mathrm{C}$ (optimum, $30^{\circ} \mathrm{C}$ ). Strain $\mathrm{BH} 030004^{\mathrm{T}}$ showed obvious Gram-, catalase- and oxidase-positive reactions and reduced nitrate to nitrite. The cells were rods, $0 \cdot 4-$ $0.9 \mu \mathrm{m}$ wide and $3 \cdot 3-4 \cdot 0 \mu \mathrm{m}$ long, and were motile by means of peritrichous flagella after 2 days incubation at $35^{\circ} \mathrm{C}$ on MA. Spherical endospores were formed in a terminal position in swollen sporangia. Analysis of the cellwall peptidoglycan of the isolate showed that the diagnostic diamino acid was meso-diaminopimelic acid (A1 $\gamma$-type). The major isoprenoid quinone was MK-7. The genomic DNA G $+C$ content was about $42 \cdot 0 \mathrm{~mol} \%$.

An almost-complete 16S rRNA gene sequence of strain BH030004 $4^{\mathrm{T}}$ was obtained and used for initial BLAST searches (http://www.ncbi.nlm.nih.gov/blast/) in GenBank and the phylogenetic analyses. The tree constructed by the neighbour-joining method showed that strain $\mathrm{BH} 030004^{\mathrm{T}}$ formed a phyletic line (with a $100 \%$ bootstrap value) distinct from the most closely related species, $P$. chungwhensis (Fig. 1). The topologies of phylogenetic trees constructed using the maximum-likelihood and maximumparsimony algorithms were similar to that of the tree constructed using neighbour-joining analysis (data not shown). The strain was most closely related to $P$. chungwhensis KCTC $3890^{\mathrm{T}}(99 \cdot 1 \% \quad 16 \mathrm{~S}$ rRNA gene sequence similarity) and it was confirmed that differences between the two sequences were mainly localized in the second variable region of the 16S RNA molecules. Levels of $16 \mathrm{~S}$ rRNA gene sequence similarity between strain $\mathrm{BH} 030004^{\mathrm{T}}$ and other related taxa were less than $95 \cdot 1 \%$. The predominant cellular fatty acids of strain $\mathrm{BH} 030004^{\mathrm{T}}$ were iso- $\mathrm{C}_{15: 0}(\sim 65 \cdot 1 \%)$, anteiso- $\mathrm{C}_{15: 0}(\sim 10 \cdot 2 \%), \mathrm{C}_{16: 1} \omega 7 c$ alcohol $(\sim 8 \cdot 8 \%)$ and iso- $\mathrm{C}_{14: 0}(\sim 4.0 \%)$ on MA (details available in a supplementary table in IJSEM Online). No significant differences in fatty acid profiles were found between cells grown on MA and those grown on MA supplemented with $3 \%(\mathrm{w} / \mathrm{v}) \mathrm{NaCl}$. Two major cellular fatty acids, iso- $\mathrm{C}_{15: 0}$ and anteiso- $\mathrm{C}_{15: 0}$, of the test strain composed about 65 and $10 \%$ of the total fatty acid content, respectively, whereas the corresponding fatty acids in P. chungwhensis KCTC $3890^{\mathrm{T}}$ accounted for about 28 and $31 \%$ of the total fatty acid content, respectively. Although 


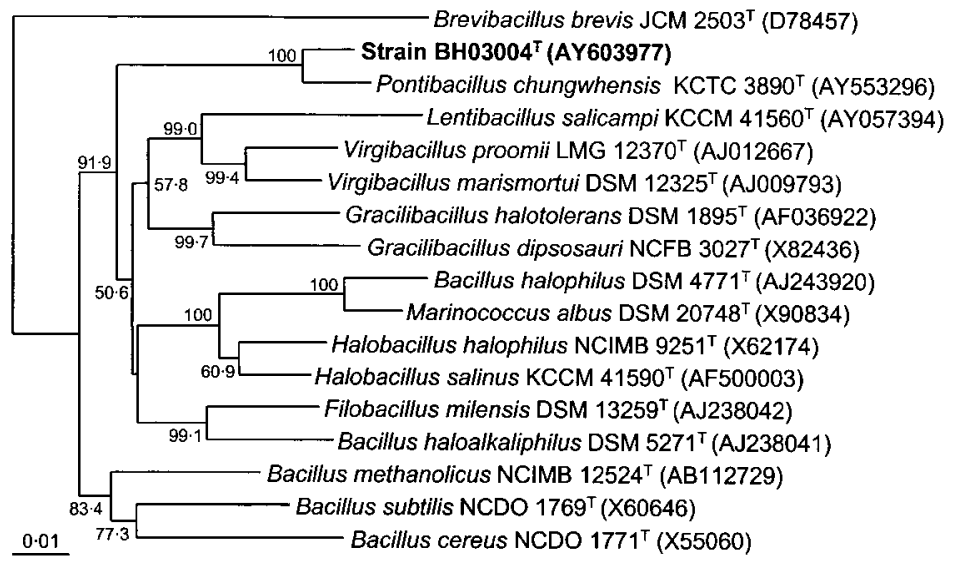

Fig. 1. Neighbour-joining tree, based on 16S rRNA gene sequences, showing the phylogenetic relationships of strain $\mathrm{BH} 030004^{\top}$ and other related taxa of low$\mathrm{G}+\mathrm{C}$ Gram-positive bacteria. Bootstrap values are shown as percentages of 1000 replicates. Brevibacillus brevis JCM $2503^{\top}$ was used as an outgroup. Bar, 0.01 changes per nucleotide position.

Table 1. Characteristics of strain $\mathrm{BH} 030004^{\top}$ and some other related species

Strains: 1, strain BH030004 ${ }^{\mathrm{T}}$; 2, P. chungwhensis DSM $16287^{\mathrm{T}}$; 3, Lentibacillus salicampi KCCM $41560^{\mathrm{T}}$; 4, Halobacillus salinus KCCM $41590^{\mathrm{T}}$; 5, Gracilibacillus halotolerans DSM $11805^{\mathrm{T}}$. Data from Lim et al. (2005), Yoon et al. (2002, 2003), Wainø et al. (1999) and this study. Symbols: +, positive; -, negative; W, weak; v, variable; NA, not available.

\begin{tabular}{|c|c|c|c|c|c|}
\hline Characteristic & 1 & 2 & 3 & 4 & 5 \\
\hline Cell size $(\mu \mathrm{m})$ & $0 \cdot 4-0.9 \times 3 \cdot 3-4 \cdot 0$ & $0 \cdot 6-0.9 \times 2 \cdot 3-3 \cdot 0$ & $0 \cdot 4-0 \cdot 7 \times 2 \cdot 0-4 \cdot 0$ & $0 \cdot 7-1 \cdot 1 \times 1 \cdot 5-4 \cdot 0$ & $0 \cdot 4-0 \cdot 6 \times 2 \cdot 0-5 \cdot 0$ \\
\hline Pigmentation & Cream & Yellow & Cream & Pale orange-yellow & Creamy white \\
\hline Gram reaction & + & + & $+1-$ & $+(\mathrm{v})$ & + \\
\hline Spore shape $e^{\star}$ & s & s & S/O & $\mathrm{E}$ & $\mathrm{E}$ \\
\hline Oxidase & + & - & + & + & + \\
\hline Nitrate reduction & + & - & NA & NA & + \\
\hline \multicolumn{6}{|l|}{ Hydrolysis of: } \\
\hline Aesculin & + & - & - & + & + \\
\hline Casein & - & + & + & + & - \\
\hline D-Glucose & - & + & NA & + & + \\
\hline D-Fructose & + & - & - & + & NA \\
\hline D-Mannitol & - & - & - & + & + \\
\hline D-Ribose & + & + & - & - & NA \\
\hline D-Xylose & - & - & - & - & + \\
\hline Maltose & + & + & - & + & NA \\
\hline D-Trehalose & + & + & - & + & NA \\
\hline Major fatty acids & iso- $\mathrm{C}_{15: 0}$ & iso- $\mathrm{C}_{15: 0}$ & anteiso- $\mathrm{C}_{15: 0}$ & iso- $\mathrm{C}_{15: 0}$ & anteiso- $\mathrm{C}_{15: 0}$, \\
\hline & $\begin{array}{c}\text { anteiso- } \mathrm{C}_{15: 0} \\
\mathrm{C}_{16: 1} \omega 7 c \text { alcohol }\end{array}$ & $\begin{array}{l}\text { anteiso- } \mathrm{C}_{15: 0}, \\
\text { iso- } \mathrm{C}_{16: 0}\end{array}$ & $\begin{array}{l}\text { iso- } \mathrm{C}_{16: 0} \\
\text { anteiso- } \mathrm{C}_{17: 0}\end{array}$ & $\begin{array}{c}\text { anteiso- } \mathrm{C}_{15: 0} \\
\text { iso- } \mathrm{C}_{16: 0}\end{array}$ & $\begin{array}{c}\mathrm{C}_{16: 0} \\
\text { anteiso- } \mathrm{C}_{17: 0}\end{array}$ \\
\hline Cell-wall typeł & $m$-DAP $(\mathrm{A} 1 \gamma)$ & $m$-DAP $(\mathrm{A} 1 \gamma)$ & $m$-DAP $(\mathrm{A} 1 \gamma)$ & L-Orn-D-Asp (A4 $\beta)$ & $m$-DAP $(\mathrm{A} 1 \gamma)$ \\
\hline
\end{tabular}

${ }^{\star} \mathrm{E}$, Ellipsoidal; O, oval; S, spherical.

$\dagger \mathrm{C}$, Central; ST, subterminal; T, terminal.

$\ddagger m$-DAP, meso-Diaminopimelic acid. 
strain $\mathrm{BH} 030004^{\mathrm{T}}$ and P. chungwhensis DSM $16287^{\mathrm{T}}$ had different fatty acid ratios, the profiles were similar. Therefore, comparative 16S rRNA gene sequence analysis clearly indicated that the novel strain was a member of the genus Pontibacillus. In addition to the results of phylogenetic analysis, many chemotaxonomic properties also supported the affiliation of the isolate to the genus Pontibacillus (Table 1).

The DNA-DNA relatedness between strain $\mathrm{BH} 030004^{\mathrm{T}}$ and P. chungwhensis KCTC $3890^{\mathrm{T}}$ was about $7 \%$, which is sufficient for classification of the novel strain as a different species (Stackebrandt et al., 2002). Phenotypic properties of strain $\mathrm{BH} 030004^{\mathrm{T}}$, including pigmentation, $\mathrm{NaCl}$ range, oxidase, nitrate reduction, hydrolyses and acid production, also supported its distinction from closely related taxa (Table 1).

On the basis of the phenotypic and phylogenetic properties, it is proposed that strain $\mathrm{BH} 030004^{\mathrm{T}}$ represents a novel species of the genus Pontibacillus, for which the name Pontibacillus marinus sp. nov. is proposed.

\section{Description of Pontibacillus marinus sp. nov.}

Pontibacillus marinus (ma'rin.us. L. masc. adj. marinus of the sea).

Cells are rods, approximately $0 \cdot 4-0 \cdot 9 \mu \mathrm{m}$ wide and $3 \cdot 3-$ $4 \cdot 0 \mu \mathrm{m}$ long, motile by means of peritrichous flagella. Spherical endospores are formed terminally in swollen sporangia. Strictly aerobic. Catalase- and oxidase-positive. Nitrate is reduced to nitrite. Colonies are cream in colour, flat, smooth and circular/slightly irregular on MA. Growth occurs at $15-40{ }^{\circ} \mathrm{C}$ (optimum, $30^{\circ} \mathrm{C}$ ), $\mathrm{pH} 6 \cdot 0-9 \cdot 0$ (opti-

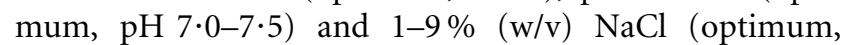
$2-5 \%)$. Tween 80 and aesculin are hydrolysed. Hydrolysis of casein, starch, gelatin, L-tyrosine, hypoxanthine, xanthine and urea is not observed. Acids are produced from sucrose, D-melibiose, D-trehalose, D-raffinose, D-fructose, D-ribose and maltose, but not from D-glucose, glycerol, D-xylose, Larabinose, L-rhamnose, $\alpha$-D-lactose, adonitol, D-mannitol, inositol or D-mannose. Major cellular fatty acids on MA are iso- $\mathrm{C}_{15: 0}(65 \cdot 12 \%)$, anteiso- $\mathrm{C}_{15: 0}(10 \cdot 15 \%), \mathrm{C}_{16: 1} \omega 7 c$ alcohol $(8 \cdot 82 \%)$ and iso- $\mathrm{C}_{14: 0}(4 \cdot 0 \%)$. DNA G $+\mathrm{C}$ content is $42 \cdot 0 \mathrm{~mol} \%$ (HPLC).

The type strain is $\mathrm{BH} 030004^{\mathrm{T}}\left(=\mathrm{KCTC} 3917^{\mathrm{T}}=\mathrm{DSM}\right.$ $16465^{\mathrm{T}}$ ), isolated from a solar saltern of the Yellow Sea in Korea.

\section{Emended description of the genus Pontibacillus Lim et al. 2005}

The description is as given by Lim et al. (2005) with the following amendments. DNA $\mathrm{G}+\mathrm{C}$ content is $40 \cdot 8-$ $42.0 \mathrm{~mol} \%$ (HPLC). On MA, predominant cellular fatty acids are anteiso- $\mathrm{C}_{15: 0}$ and iso- $\mathrm{C}_{15: 0}$.

\section{Acknowledgements}

This work was supported by the 21C Frontier Microbial Genomics and Application Center Program, Ministry of Science \& Technology (grant MG05-0101-1-0).

\section{References}

Ash, C., Farrow, J. A. E., Wallbanks, S. \& Collins, M. D. (1991). Phylogenetic heterogeneity of the genus Bacillus as revealed by comparative analysis of small-subunit ribosomal-RNA sequences. Lett Appl Microbiol 13, 202-206.

Cole, J. R., Chai, B., Marsh, T. L. \& 8 other authors (2003). The Ribosomal Database Project (RDP-II): previewing a new autoaligner that allows regular updates and the new prokaryotic taxonomy. Nucleic Acids Res 31, 442-443.

DeLong, E. F. (1992). Archaea in coastal marine environments. Proc Natl Acad Sci U S A 89, 5685-5689.

Felsenstein, J. (2002). PHYLIP (phylogeny inference package), version 3.6a. Seattle: University of Washington.

Heyndrickx, M., Lebbe, L., Kersters, K., De Vos, P., Forsyth, G. \& Logan, N. A. (1998). Virgibacillus: a new genus to accommodate Bacillus pantothenticus (Proom and Knight 1950). Emended description of Virgibacillus pantothenticus. Int J Syst Bacteriol 48, 99-106.

Heyrman, J., Logan, N. A., Busse, H. J., Balcaen, A., Lebbe, L., Rodriguez-Diaz, M., Swings, J. \& De Vos, P. (2003). Virgibacillus carmonensis sp. nov., Virgibacillus necropolis sp. nov. and Virgibacillus picturae sp. nov., three novel species isolated from deteriorated mural paintings, transfer of the species of the genus Salibacillus to Virgibacillus, as Virgibacillus marismortui comb. nov. and Virgibacillus salexigens comb. nov., and emended description of the genus Virgibacillus. Int J Syst Evol Microbiol 53, 501-511.

Komagata, K. \& Suzuki, K. (1987). Lipid and cell-wall analysis in bacterial systematics. Methods Microbiol 19, 161-208.

Lanyi, B. (1987). Classical and rapid identification methods for medically important bacteria. Methods Microbiol 19, 1-67.

Leifson, E. (1963). Determination of carbohydrate metabolism of marine bacteria. J Bacteriol 85, 1183-1184.

Lim, J.-M., Jeon, C. O., Song, S. M. \& Kim, C.-J. (2005). Pontibacillus chungwhensis gen. nov., sp. nov., a moderately halophilic Grampositive bacterium from a solar saltern in Korea. Int J Syst Evol Microbiol 55, 165-170.

Nielsen, P., Rainey, F. A., Outtrup, H., Priest, F. G. \& Fritze, D. (1994). Comparative 16S rDNA sequence analysis of some alkaliphilic bacilli and the establishment of a sixth rRNA group within the genus Bacillus. FEMS Microbiol Lett 117, 61-66.

Schlesner, H., Lawson, P. A., Collins, M. D., Weiss, N., Wehmeyer, U., Völker, H. \& Thomm, M. (2001). Filobacillus milensis gen. nov., sp. nov., a new halophilic spore-forming bacterium with Orn-D-Glutype peptidoglycan. Int J Syst Evol Microbiol 51, 425-431.

Spring, S., Ludwig, W., Marquez, M. C., Ventosa, A. \& Schleifer, K. H. (1996). Halobacillus gen. nov., with descriptions of Halobacillus litoralis sp. nov., and Halobacillus trueperi sp. nov., and transfer of Sporosarcina halophila to Halobacillus halophilus comb. nov. Int J Syst Bacteriol 46, 492-496.

Stackebrandt, E. \& Liesack, W. (1993). Nucleic acids and classification. In Handbook of New Bacterial Systematics, pp. 152-189. Edited by M. Goodfellow \& A. G. O’Donnell. London: Academic Press.

Stackebrandt, E., Frederiksen, W., Garrity, G. M. \& 10 other authors (2002). Report of the ad hoc committee for the 
re-evaluation of the species definition in bacteriology. Int J Syst Evol Microbiol 52, 1043-1047.

Tamaoka, J. \& Komagata, K. (1984). Determination of DNA base composition by reverse-phase high-performance liquid chromatography. FEMS Microbiol Lett 25, 125-128.

Thompson, J. D., Higgins, D. G. \& Gibson, T. J. (1994). CLUSTAL W: improving the sensitivity of progressive multiple sequence alignment through sequence weighting, position-specific gap penalties and weight matrix choice. Nucleic Acids Res 22, 4673-4680.

Wainø, M., Tindall, B. J., Schumann, P. \& Ingvorsen, K. (1999). Gracilibacillus gen. nov., with description of Gracilibacillus halotolerans gen. nov., sp. nov.; transfer of Bacillus dipsosauri to Gracilibacillus dipsosauri comb. nov., and Bacillus salexigens to the genus Salibacillus gen. nov., as Salibacillus salexigens comb. nov. Int J Syst Bacteriol 49, 821-831.

Yoon, J.-H., Kim, H., Kim, S.-B., Kim, H.-J., Kim, W. Y., Lee, S. T., Goodfellow, M. \& Park, Y.-H. (1996). Identification of Saccharomonospora strains by the use of genomic DNA fragments and rRNA gene probes. Int J Syst Bacteriol 46, 502-505.

Yoon, J. H., Kang, K. H. \& Park, Y. H. (2002). Lentibacillus salicampi gen. nov., sp. nov., a moderately halophilic bacterium isolated from a salt field in Korea. Int J Syst Evol Microbiol 52, 2043-2048.

Yoon, J. H., Kang, K. H. \& Park, Y. H. (2003). Halobacillus salinus sp. nov., isolated from a salt lake on the coast of the East Sea in Korea. Int J Syst Evol Microbiol 53, 687-693. 